\section{No. 1-4}

\section{Preface}

Smith, J. (Roslin); Nanda, I. (Würzburg)

Introduction

6 Avian genomics in the 21 st century

Burt, D.W. (Roslin); White, S.J. (Cambridge)

\section{Resources}

14 The chicken RH map: current state of progress and microchromosome mapping

Morisson, M.; Denis, M.; Milan, D.; Klopp, C.; Leroux, S.; Bardes, S. Pitel, F.; Vignoles, F.; Gérus, M.; Fillon, V.; Douaud, M.; Vignal, A. (Castanet-Tolosan)

22 A high-resolution linkage map for the $Z$ chromosome in chicken reveals hot spots for recombination

Wahlberg, P.; Strömstedt, L.; Tordoir, X. (Uppsala); Foglio, M.; Heath, S.; Lechner, D. (Evry); Hellström, A.R. (Uppsala);

Tixier-Boichard, M. (Jouy-en-Josas); Lathrop, M.; Gut, I.G. (Evry); Andersson, L. (Uppsala)

30 GEISHA: an in situ hybridization gene expression resource for the chicken embryo

Darnell, D.K.; Kaur, S.; Stanislaw, S.; Davey, S.; Konieczka, J.H.; Yatskievych, T.A.; Antin, P.B. (Tucson, AZ)

36 Practicable approaches to facilitate rapid and accurate molecular cytogenetic mapping in birds and mammals Morris, W.B.; Stephenson, J.E.; Robertson, L.B.W.; Turner, K.; Brown, H.; Ioannou, D.; Tempest, H.G.; Skinner, B.M.; Griffin, D.K. (Canterbury)

Cytogenetics

43 Chromosome repatterning in three representative parrots (Psittaciformes) inferred from comparative chromosome painting

Nanda, I.; Karl, E. (Würzburg); Griffin, D.K. (Canterbury);

Schartl, M.; Schmid, M. (Würzburg)

54 Chromosomal mapping of chicken mega-telomere arrays to GGA9, 16, 28 and W using a cytogenomic approach

Delany, M.E.; Gessaro, T.M.; Rodrigue, K.L.; Daniels, L.M. (Davis, CA)

64 The evolution of the avian genome as revealed by comparative molecular cytogenetics

Griffin, D.K.; Robertson, L.B.W; Tempest, H.G.; Skinner, B.M. (Canterbury)
Evolution

78 Conserved synteny of mammalian imprinted genes in chicken, frog, and fish genomes

Dünzinger, U.; Haaf, T.; Zechner, U. (Mainz)

$86 Z P$ genes in avian species illustrate the dynamic evolution of the vertebrate egg envelope Hughes, D.C. (Nottingham)

92 Different origins of bird and reptile sex chromosomes inferred from comparative mapping of chicken Z-linked genes

Kawai, A.; Nishida-Umehara, C.; Ishijima, J.; Tsuda, Y. (Sapporo); Ota, H. (Nishihara); Matsuda, Y. (Sapporo)

103 A new look at the evolution of avian sex chromosomes Stiglec, R.; Ezaz, T.; Graves, J.A.M. (Canberra)

110 Sequencing and genomic annotation of the chicken (Gallus gallus) Hox clusters, and mapping of evolutionarily conserved regions

Richardson, M.K. (Leiden); Crooijmans, R.P.M.A.; Groenen, M.A.M. (Wageningen)

120 Molecular evolutionary genomics of birds Ellegren, H. (Uppsala)

Gene Expression

131 Global gene expression profile after Salmonella enterica Serovar enteritidis challenge in two F8 advanced intercross chicken lines

Zhou, H. (Ames, IA/College Station, TX); Lamont, S.J. (Ames, IA)

139 A functional genomics approach to the study of avian innate immunity

Keeler, C.L., Jr.; Bliss, T.W. (Newark, DE); Lavrič, M. (Domžale); Maughan, M.N. (Newark, DE)

146 Evolutionary conservation of alternative splicing in chicken

Katyal, S.; Gao, Z.; Liu, R.-Z.; Godbout, R. (Edmonton)

158 Manipulation of small RNAs to modify the chicken transcriptome and enhance productivity traits Tizard, M.L.V.; Moore, R.J.; Lambeth, L.S.; Lowenthal, J.W.; Doran, T.J. (Geelong)

165 Avian sex determination: what, when and where? Smith, C.A.; Roeszler, K.N. (Parkville); Hudson, Q.J. (Bar Harbor, ME); Sinclair, A.H. (Parkville)

174 Manipulation of thyroid status and/or GH injection alters hepatic gene expression in the juvenile chicken Wang, X. (Newark, DE/Nashville, TN); Carré, W. (Newark, DE/ Midlothian); Saxton, A.M. (Knoxville, TN); Cogburn, L.A. (Newark, DE) $\begin{array}{ll}\text { KARGER } & \text { Fax }+41613061234 \\ \text { E-Mail karger@karger.ch }\end{array}$

(C) 2007 S. Karger AG, Basel www.karger.com
Access to full text and tables of contents, including tentative ones for forthcoming issues: www.karger.com/cgr_issues 
Immunology

189 Biotechnology and the chicken B cell line DT40 Bachl, J.; Caldwell, R.B.; Buerstedde, J.-M. (Neuherberg-Munich)

195 Genomics of antiviral defenses in the duck, a natural host of influenza and hepatitis $B$ viruses MacDonald, M.R.W.; Veniamin, S.M.; Guo, X.; Xia, J.; Moon, D.A.; Magor, K.E. (Edmonton)

207 Avian genomics and the innate immune response to viruses

Jenkins, K.A.; Bean, A.G.D.; Lowenthal, J.W. (Geelong)

213 Characterization of the turkey MHC chromosome through genetic and physical mapping Chaves, L.D.; Krueth, S.B.; Reed, K.M. (St. Paul, MN)

221 The avian immune genome - a glass half-full or half-empty?

Kaiser, P. (Compton)

Development

231 The chicken as a model for embryonic development Davey, M.G. (Roslin); Tickle, C. (Dundee)

240 Potential application of sperm bearing female-specific chromosome in chickens

Shimada, K.; Valdez, M.B., Jr.; Mizutani, M.; Namikawa, T. (Nagoya)

248 Low density lipoprotein receptor relatives in chicken ovarian follicle and oocyte development Schneider, W.J. (Vienna)

256 Left-right axis development: examples of similar and divergent strategies to generate asymmetric morphogenesis in chick and mouse embryos Schlueter, J.; Brand, T. (Würzburg)

Sequence Analysis

268 Characterising alternate splicing and tissue specific expression in the chicken from ESTs

Tang, H.; Heeley, T.; Morlec, R.; Hubbard, S.J. (Manchester)

278 GOing from functional genomics to biological significance

McCarthy, F.M.; Bridges, S.M.; Burgess, S.C. (Mississippi State, MS)

Quantitative Trait Loci and Single Nucleotide Polymorphism

288 Identification of quantitative trait loci affecting shank length, body weight and carcass weight from the Japanese cockfighting chicken breed, Oh-Shamo (Japanese Large Game)

Tsudzuki, M.; Onitsuka, S.; Akiyama, R.; Iwamizu, M.; Goto, N.; Nishibori, M. (Higashi-Hiroshima); Takahashi, H. (Tsukuba); Ishikawa, A. (Nagoya)

296 Quantitative trait loci for bone traits segregating independently of those for growth in an

$F_{2}$ broiler $\times$ layer cross

Sharman, P.W.A. (Edinburgh/Roslin); Morrice, D.R.; Law, A.S.; Burt, D.W.; Hocking, P.M. (Roslin)

305 Parent-of-origin specific QTL - a possibility towards understanding reciprocal effects in chicken and the origin of imprinting

Tuiskula-Haavisto, M.; Vilkki, J. (Jokioinen)
313 Evidence for widespread epistatic interactions influencing Marek's disease virus viremia levels in chicken

Cheng, H.H. (East Lansing, MI); Zhang, Y. (Beijing); Muir, W.M. (West Lafayette, IN)

319 Biodiversity of 20 chicken breeds assessed by SNPs located in gene regions

Twito, T. (Rehovot/Bet Dagan/Ramat-Gan); Weigend, S. (Mariensee); Blum, S. (Rehovot); Granevitze, Z. (Rehovot); Feldman, M.W. (Stanford, CA); Perl-Treves, R. (Ramat-Gan); Lavi, U. (Bet Dagan); Hillel, J. (Rehovot)

327 Detection of agriculturally important QTLs in chickens and analysis of the factors affecting genotyping strategy

Atzmon, G.; Blum, S. (Rehovot); Feldman, M. (Stanford, CA); Lavi, U. (Bet Dagan); Hillel, J. (Rehovot)

338 Extent of linkage disequilibrium in chicken

Aerts, J. (Wageningen/Roslin); Megens, H.J.; Veenendaal, T.

(Wageningen); Ovcharenko, I. (Livermore, CA); Crooijmans, R.

(Wageningen); Gordon, L.; Stubbs, L. (Livermore, CA); Groenen, M.

(Wageningen)

Genes and Longevity

346 Fanconi anemia: genetic analysis of a human disease using chicken system

Takata, M.; Kitao, H. (Hiroshima); Ishiai, M. (Kurashiki)

352 Neuroendocrine and immune characteristics of aging in avian species

Ottinger, M.A.; Lavoie, E. (College Park, MD)

Proteomics

358 Avian proteomics: advances, challenges and new technologies

Doherty, M.K.; McLean, L.; Beynon, R.J. (Liverpool)

Avian Viruses

370 Polymorphisms of the chicken antiviral $M X$ gene Watanabe, T. (Sapporo)

376 Genomics and Marek's disease virus Burnside, J.; Morgan, R.W. (Newark, DE)

388 Modulation of macrophages by infectious bursal disease virus

Khatri, M.; Sharma, J.M. (St. Paul, MN)

394 Genesis of pandemic influenza Sorrell, E.M. (College Park, MD); Ramirez-Nieto, G.C. (College Park, MD/Bogota); Gomez-Osorio, I.G.; Perez, D.R. (College Park, MD)

403 Author Index Vol. 117, 2007 